\title{
TCOM \\ Climate change news reporting in Pakistan: a qualitative analysis of environmental journalists and the barriers they face
}

\section{Asim Sharif and Fabien Medvecky}

\begin{abstract}
Climate change is a global risk as its causes and effects are not limited to national borders, but the risks and the responsibility are not evenly spread [Beck, 2009]. Pakistan is facing especially severe impacts in the form of disasters, floods, droughts, rising temperatures, cyclones and rising sea levels due to global emissions, despite its national emissions being nominal and accounting for only $0.46 \%$ of worldwide emissions [World Bank, 2018]. Ironically, the level of public awareness of climate change is low in Pakistan compared to not only advanced countries, but also to other countries in the South Asian region [Zaheer and Colom, 2013]. A contributing factor behind this is the communication gap between the media and the broader public. This study aims to explore the factors responsible for the limited coverage of climate change in the news media, leading to confusion, uncertainty, denial and low levels of climate change awareness in Pakistan. Qualitative semi-structured interviews were conducted with media professionals and the findings show that political, economic, social, cultural, technological and scientific factors influence the news coverage of climate change issues.
\end{abstract}

Keywords

DOI

Introduction and background
Environmental communication; Science and media; Science communication in the developing world

https://doi.org/10.22323/2.17010203
Climate change is a global risk as its causes and effects are not limited to national borders, and involve numerous stakeholders [Beck, 2009]. The last two decades witnessed a ballooning growth of media scholarship on climate change with a major focus on media coverage of issues of national and global importance in the forms of national case studies, comparative studies, cross-sectional studies and longitudinal studies around the world and in different news settings such as print, electronic and online media [Hansen, 2015; Schäfer and Schlichting, 2014]. However, the share of Asian scholars is only $4.6 \%$ of the total media research conducted on climate change communication [Schäfer and Schlichting, 2014]. From a methodological perspective, there are slightly more quantitative research papers $(47.8 \%)$ than qualitative research papers $(44.85 \%)$ while the remaining $7.5 \%$ of research papers adopt mixed approaches. And the majority of these studies 
document the trend sin news coverage of climate change issues, generally showing an upward tendency over the years in both national and cross-national contexts.

In this study, we ask: what barriers are there to providing adequate coverage of climate change issues in the Pakistani news media? This was motivated both by wanting to bring to light some of the rarely studied issues experienced in a global south country, one that is both especially vulnerable to climate change, and one that has some of lowest levels of climate change news coverage in its media.

Pakistani news media and climate change coverage
Pakistani media is a vibrant source of information for its diverse audience and is comprised of electronic, print and online media. In electronic media, television is considered to be the most popular media for information and entertainment purposes and can be further categorized into 'terrestrial channels' such as the state-owned Pakistan television corporation, 'cable channels' like Dawn, ARY, Express, Geo Dunya and Sama TV, and 'satellite channels' like Al-Jazeera, CNN, Fox, BBC [Ricchiardi, 2012]. This is followed by radio, whose use is facilitated by the rapid growth of cellular networks in Pakistan. There are 162 private radio stations but state owned radio networks, Voice of America and BBC Urdu are some of the more reliable sources of news and information. The print media landscape of Pakistan is comprised of 252 daily newspapers, 139 weeklies, and 279 monthlies publications. Dawn, Nawai-Wakat, Jang, and Express Tribune are the leaders in the print media market in terms of circulation [Ricchiardi, 2012]. Importantly, the Pakistani media landscape is not complete without news agencies. There is one state owned agency (Associated Press of Pakistan), and two privately owned news agencies, namely 'Pakistan Press International' and 'Online News Network International'. These feed news and images to both national and international media outlets [Ricchiardi, 2012]. Apart from this, a rapid growth in the telecommunication industry combined with increased access to the Internet has paved the way for online news outlets and web TV in Pakistan. Almost all the media broadcasters having an online presence, and web channels such as Zem TV, GEO, Dawn, Express Ary, Dunya, AJ TV, BBC and Voice of America are popular sources of news among Pakistani web users [Yusuf, 2008].

In contrast to global media research on climate change, including those from an Asian perspective such as India, Bangladesh, Nepal, Sri Lanka etc., Pakistan's contribution to media and climate change research is almost non-existent [Kim, 2011]. A few studies have been conducted by national and international scholars but these are only limited to the content analysis of newspapers. For instance, Boykoff [2011] analysed the coverage of climate change issues in Pakistani print and found it to be limited and inadequate. Similarly, Ali's study [2010] found that Pakistani Urdu news media hardly reports on climate change issues when compared to the Pakistani English news. One of the more robust findings comes from the National Council of Environment Journalists (NCEJ) which quantitatively analysed the coverage of climate change issues over the electronic news media and records that $2.8 \%$ of total news coverage is given to environmental news [TNN, 2014]. From the above discussion, we see that the Pakistani media does not discuss climate change as well or as often as most other countries. Additionally, research on the Pakistani media's reporting of climate change is largely limited to quantitative analysis focused only on the print media, with little or no scholarly empirical studies on either electronic or online media, and no qualitative analysis 
to provided an insight as to why the Pakistani media might be lagging behind much of the rest of the world when it comes to covering climate change issues.

Theoretical and empirical review of climate change news coverage
A critical review of media and climate change scholarship suggests three dominant frameworks for the analysis of media coverage on climate change issues. These are that the political-economic approach, the structural approach, and the socio-cultural approaches [Anderson, 2009].

\subsection{Political-economic approach}

Proponents of the political-economic approach argue that the media works within certain rules and regulations (such as formal state control, or privatised systems) and relies on financial returns gained through advertising or subsidies for its survival. It therefore serves the interests of those having the political and economic means to control news production and content [Cottle, 2000; Allan, 2004; Cox, 2013; Cox, 2015]. A large number of studies indicate the political and economic influence of state machinery, multinational corporations, and fuel lobby on the media results in lowering the level of climate change reporting [Beder, 2002; Gelbspan, 2005; Antilla, 2005; Monbiot, 2006; Boykoff and Boykoff, 2004; Boykoff and Boykoff, 2007; Djerf-Pierre, 2012]. Thus, political-economic approaches provide a conceptual background for scholarly research on climate change news coverage.

\subsection{Structural approach}

The structural approach discusses the news culture of media organizations in terms of news-values/norms, and news gathering sources that influences the media coverage of climate change issues. According to Hansen [2010], climate change news gets the attention of the media only when it is event oriented, having strong visual appeal and suitable to a 24-hour news cycle. For Miller and Riechert [2000] conflict is another news-value for climate change, and Cottle [2013] argues that cultural proximity is an important news-value for the media in selecting climate change stories. Climate change debates, then, become news only when it has all or some of the news-values that determine the selection criteria of journalists and news editors working for different news media organizations. Boykoff's [2004; 2007] studies reveal that journalistic norms like 'personalization, balance, dramatization, and novelty' influenced US media coverage of climate change issues between the period of 1988 to 2004, but only very few such study has been carried out with regard to South Asian climate change reporting [see Rhaman, 2012, as an example]. In addition to this, the availability of news sources is positively correlated with the amount of coverage climate change issues get [Allan, 2004]. A critical review of media research indicates that when reporting on climate change, news media outlets depend most on official sources, followed by NGOs, then industry and less on direct access to scientists [Cox, 2013; Cottle, 2000]. Looking at the structure of the news media landscape gives us another approach to understand the coverage of climate change issues in the media. 


\subsection{Socio-cultural approach}

The third framework to understand the news media coverage of climate change is the socio-cultural approach. Hilgartner and Bosk [1988] argue that the media embraces all the 'cultural preoccupations and political biases' of its social environment. Problems and issues that are close to the cultural beliefs, norms and values of a media outlet's society get attention at the expense of other topics [Gamson and Modigliani, 1989]. Applying this framework to climate change coverage, scholars argue that climate change issues only receive media attention when they resonate well with the media outlet's socio-cultural environment. For example, a socially embedded view of 'nature as something to be protected' increases the amount of coverage of climate change issues, whereas a view of 'nature as an object of control and exploitation' lowers the priority of climate change among other social issues [Anderson, 2009, p. 10]. Thus, the prevailing socio-cultural milieu helps shape the relative importance of climate change issues, debates, and policy measures, resulting in an increase (or decrease) in media representation of these issues. This, in turn, helps shape public knowledge and interest, creating a feedback loop [Anderson, 2009].

Methodology

\subsection{Data collection}

Taking a 'social constructionism approach' [Berger and Luckmann, 1966], we used qualitative semi-structured interviews [Gill et al., 2008]. In such interviews, the researcher conducts face-to-face interviews with the media experts who then construct reality on the basis of their life-long professional experiences. Keeping this in mind, we used a case study approach to identify our target population of environmental journalists residing and working for different media outlets in the two cities of Islamabad and Rawalpindi. A major challenge was that there is no regular branch of environmental journalism in Pakistan, rather it is considered an additional task assigned to a generic reporter. Consequently, a 'very low visibility' of environmental journalism is observed in the Pakistani media [Biernacki and Waldorf, 1981]. We addressed this problem by using a chain referral sampling strategy to yield a professional-demographic sample of relevant journalists, which provided us a way to access a network of environmental journalists. Recruitment was carried out until we reached saturation of themes [Bygnes, 2008; Undheim, 2003; Sullivan, 2004; Biernacki and Waldorf, 1981]. We began this snowball through contacts working as Bureau-In-Chief, Director of News, and News Editors in leading media groups, including Geo, ARY, Express and Dawn. This culminated in a total of 30 respondents made up of 11 journalists from TV and radio, 10 from print media, 6 from online media, and 3 from news agencies. From the print media, 4 journalists came from Urdu newspapers, 6 from English newspapers. From the TV and radio cohort, 9 worked in television news and 2 in radio. And of the 6 online journalists recruited, 3 came from online newspapers and the other 3 were from Web TV outlets. To put our sample size into perspective, we interviewed 30 environmental journalists from an engaged population of approximately 50 (see appendix A for details). We opted for face-to-face interviews as this provides a natural setting for interaction with interviewees and for capturing non-verbal cues such as body language.

Prior to beginning the interviewing phase, we devised an interview guide following standard semi-structured interviewing methodology. In devising the 
guide, we progressed from general questions to specific questions (see appendix B for the interview guide). We conducted a pilot study to rectify the flaws and weaknesses and revised the guide accordingly [Kvale, 2007]. During the interviews, we explained the purpose of the interview and sought consent before beginning the formal process. We encouraged interviewees to share their personal experiences by telling them that there is no right or wrong answer. We followed the interview guide and probed where more detail seemed required [Hutchinson and Wilson, 1992]. At the end of each interview, we took field notes of important ideas, terms and phrases and transferred the data from tape recorder to hard drive for transcribing and analysis purposes. All interviews were carried out in the Urdu language.

\subsection{Data analysis}

We transcribed the data in the original Urdu as one of the researchers is a native Urdu speaker. We used an Interpretative Phenomenological Analysis (IPA) approach "to explore in detail how participants are making sense of their personal and social world" [Smith, Larkin and Flowers, 2009, p. 54]. IPA is a two-stage process because "the researcher is trying to make sense of the participants trying to make sense of their world" [Smith and Osborn, 2007, p. 67]. We followed standard practice in IPA to enable us to locate ideas, similarities and differences, and possible connections between paragraphs throughout the text [Smith and Osborn, 2007, p. 82]. We used the processes of 'subsumption' and 'abstraction' on one hand and 'polarization' on the other, and discarded those themes that failed to get sufficient evidence. This led to the formation of a final table having a list of themes. We repeated the process with each interview until we had a master table with nested themes from the various transcripts. According to Smith, a one-third recurrence of themes "enhance[s] the validity of the findings of a large corpus" [Smith, Larkin and Flowers, 2009, p. 107] and in our case, there is a high degree of convergence among environmental journalists working for different media outlets. Our analytical process came to an end with the identification of themes which form the basis of our findings (see appendix $C$ for a nested list of themes).

\section{Findings}

When asked about the news media coverage of climate change, the majority of journalists (27) share the view that the Pakistani media does not project this issue at a national level. They believe that Pakistan's media has confined the subject of climate change to event-oriented coverage (such as news about weather forecasts, conferences, press briefings and press releases etc.) As a TV news reporter explains:

\footnotetext{
"You know, in Pakistan... most of the time it's always events, not the issue of climate change which is covered, so if there are some events like floods huge floods - or there are some events like famine, or drought, or something like that... most of the time we cover events, we don't cover climate change as a phenomenon..." (Interview 4, p. 1).
}

Furthermore, there was consensus among all 30 journalists that information about global climate change, its future challenges and its impact, were minimal in Pakistan's national news media outlets. In brief, the media covers climate change 
issues only when it is reported in foreign media. As one electronic media journalist states:
"The national media does not cover climate change at all because, as I have told you, whenever some big incident happened, some huge disaster occurred $[\ldots]$ if a bulletin of $9.00 \mathrm{pm}$ is going on and breaking news came in [...] the bulletin is going on so we drop the weather - this I am talking about electronic media. In print, too there is some single line small story or simple column is published. In English newspapers like the Daily Times or Dawn, if there is story, then it is published on the front five columns or on four columns. The English media covers it [climate change] a little bit but Urdu does not $[\ldots]$. We cover only when it is reported by BBC, CNN." (Interview 9, p. 4).

When probing further as to why climate change is not getting adequate coverage, a number of factors were revealed, specifically financial, political, cultural, technological and scientific factors.

\subsection{Financial factors}

Monetary support is an important factor influencing the news media coverage of climate change issues. To this end, most of the respondents (23 out of 30 ) stated that the media operates on a business model that depends upon advertisements and subscriptions from the public and private sectors. As far as climate change coverage is concerned, there is little revenue to be had from it as there are no advertisements or subsidies from either state or non-state actors. As a result, the media does not project the issue of climate change as much as other more financially incentivised topics. As one electronic media journalist comments:

\footnotetext{
"The question is who will give money to news house to engage in investigative journalism in the climate change domain with the outcome of good news stories on climate change? Climate change reporting needs financial sponsorships. No funding leads to poor coverage of climate change news..." (Interview 13, p. 4).
}

A few journalists (7) believe that both government and non-government organizations are receiving funds from international bodies for promoting climate change awareness, but these funds are not reaching the media despite being intended to run advertising campaigns highlighting environmental issues. As a result, the media does not give much attention to climate change issues.

In brief, the Pakistani media has limited resources in terms of finance to support and validate meaningful reporting on climate change.

\subsection{Political factors}

The majority of interviewed journalists (29 out of 30) claim that Pakistan's media is a deeply politics-centric media and focuses more on political news than on any other topics. Importantly, unlike many western countries where climate change is a deeply political issue [Boykoff and Boykoff, 2007], in Pakistan, climate change is discussed so little it even fails to get traction in political discourse (Interview 22, 23, 27, 30). A resident editor of an Urdu newspaper agrees stating: 
"The media should look at its programs - 80-90\% of the time and duration is given to politics. In all the debates, all the negotiations, all the interviews, and the people we meet, we only discuss politics." (Interview 8, p. 4).

Importantly, a number of journalists (14 out of 30) argue that political reporting is prestigious in journalistic circles. Political reporters enjoy fame, benefits such as foreign tours, and rewards like posts and foreign scholarships. However, such gains do not await those reporting on environmental issues, hence the lack of will for reporting on issues such as climate change.An editor explains:

"The best reporter, we keep him for politics - to deal with political issues, or parliament." (Interview 25, p. 7).

A small portion of journalists (7) also claim that owners and editors have political affiliations with the ruling and opposition parties and this affects the editorial policy of the media houses, leading them to push coverage towards the political issues of interest to their affiliations. And as stated above, climate change is not a part of the Pakistani political landscape, rendering it invisible. An Urdu news channel editor states:

"So if the editors were sitting here or the senior people in journalism, they are also kind of - I would say politics is very dear to them, they want recognition from the political elite... they are linked with different political parties, they support their party and criticise other parties, and they are spending most of their time on politics." (Interview 24, p. 7).

Indeed, the dominance of politics in the news media landscape eclipses the climate change coverage.

\subsection{Cultural factors}

The third point is that the culture of news reporting in Pakistan does not promote climate change reporting. Respondents believe that there is no culture of specialized treatment of environmental news, both in the Urdu and English news media, so no regular coverage of climate change occurs.

As one news agency editor states:

\footnotetext{
"In our national media, there is a regular news branch of reporting for its individuals, for every issue there is a branch of every reporter. For example, one who does politics - he only does politics most of the times. The print media - in the traditional print media, we do not keep a separate reporter for climate change." (Interview 28, p. 8).
}

This culture manifests itself in various ways. Firstly, and related to the previously mentioned point about the prestige of political reporting and the associated lack of prestige for environmental reporting, a standard approach is to link climate change to non-governmental organizational (NGO) agendas, so the most junior staff ends 
up covering the story. Such junior staff often have little understanding of climate change. Hence they focus their attention on the NGO activities themselves, and on pinpointing the NGO's milestones instead of discussing climate change issues per se (Interview 30, 14, 17, 19).

Secondly, the Pakistani media is imbedded in a 'breaking news syndrome' culture of 'hot and spicy news' such as political rivalries, sectarian conflicts, crime, acts of violence, bomb blasts, and disasters providing the sensational material to satisfy the 'syndrome' (Interview, 2, 8, 17, 19). A number of respondents have claimed that the primary purpose of reporting is to increase newspaper readership or channel viewership, at the detriment of informative content. This is related to the financial factors discussed above and is not unique to Pakistan. Still, as climate change reporting has no sensational element for Pakistani audiences, it is worth noting the effect of this news culture on the volume of climate change stories in the media (Interview, 4, 5, 6, 13, 25, 30). A news director explains the reason behind the limited amount of climate change news:

\begin{abstract}
"The media is basically a sensationalist media, specifically, TV in Pakistan. So, most of the times, they are in search of spicy news, in which political controversies and political conflicts are included. So, it is this they think that people will enjoy. Their rating is increased in this way - because people watch it more. Similarly, serious journalism, even if it is related to issues of education, issues of health or issues of climatic change - the media is not ready to give importance to such issues."(Interview 21, p. 6).
\end{abstract}

Thus, the culture of Pakistan journalism is to have a preference for sensational and dramatized news stories rather than informative content such as climate change, and politics is viewed as the core topic to generate such sensational stories.

\title{
5.4 Technological and scientific factors
}

A large proportion of the interviewed media professionals (23 out of 30) claim that local journalists are laggards in the use of technology. Media organizations have limited financial resources to provide the journalistic tools required to cover issues such as climate change. Indeed, local journalists are not always computer literate, and even when they are, they face limited access to the Internet. This allows for little interaction with online climate change sources such as data banks, official websites and portals of international organizations. All this leads to poor coverage of climate change issues at the local level. An Urdu newspaper reporter states:

"We lack equipment and tools — tape recorders, laptops and software. We do not have knowledge of information and technologies, we do not know how to use computer software, how to surf the Internet." Interview 26, p. 8).

And scientifically, for more than half of the respondents (17 out of 30), climatologists should be the main source of information but they are limited in number in Pakistan. Furthermore, they (journalists) have little to no interaction with climate change experts due to problems accessing climatologists working in state institutions, NGOs, and at universities (Interviews 3, 9, 23, 28). In most cases, 
local journalists rely upon meteorologists, agriculturists and other physical sciences experts working in public and private institutions, but limited access hinders any meaningful reporting of climate change issues. A news agency editor explains:

\footnotetext{
"Here you cannot even find an expert to quote. If you look, then you can see that not many books have been written related to this topic, no articles have been written." (Interview 29, p. 8).
}

And the lack of interaction goes both ways with a number of reporters arguing that scientists working in state departments are not willing to share their research findings with journalists until they get approval from senior bureaucrats (Interviews 1, 4, 5, 8, 17). As one TV news director states:

\begin{abstract}
"But the problem is that neither do environmental scientists go to the officials of newspaper to say that, "Brother! I have completed my research, so publish it", nor do the newspapers attempt to go to the scientists." (Interview 22, p. 7).
\end{abstract}

In brief, the lack of basic technical knowledge, and challenges in accessing expertise and resources, including the scarcity of climate change experts, are a contributing factor for the low levels of climate change stories in the Pakistani news.

The Pakistani media does not, seemingly, give climate change issues sufficient coverage, not only in relation to international standards, but also in relation to regional standards [Hansen, 2015; Cox, 2015]. The findings of our study reflect the current literature in media studies that political, economic, social, cultural, technological and scientific factors are drivers of such low level of coverage. Taking the political-economical approach, our results show that the Pakistani media indeed works within certain rules and regulations, and relies on financial returns gained primarily through advertising. In terms of overt rules and regulations, Pakistani media is fairly open, though when thinking specifically about climate change, a lack of access to scientific expertise is a clear hindrance. More interestingly, Pakistan's relationship with politics makes the political-economical nexus an especially interesting one because political news is what is perceived as generating interesting news content (and thereby generating advertising revenue). Surprisingly, climate change is not viewed as a political issue. While this may be a blessing in some contexts, in a media landscape like Pakistan's where politics dominate, not being a political issue means being made invisible, and this is largely what can be seen with regard to climate change [Cottle, 2000; Allan, 2004; Cox, 2013; Cox, 2015].

Looking at Pakistan's coverage of climate change from the socio-cultural approach and at Pakistan's 'cultural preoccupations and political biases' [Gamson and Modigliani, 1989], it is important to recognise that Pakistan is dominated by political and ethnic unrest, a dwindling economy, and the on-going war on terror against the Taliban. This is reflected in the media whose top priority is reporting on political and national security issues, and on economic stability. Climate change coverage increases only when natural disasters take place, and even then, it is debated and analysed from social and cultural perspectives. In Pakistan, the 
environment is not a top priority and consequently, climate change rates at the bottom of news priorities [Hilgartner and Bosk, 1988; Gamson and Modigliani, 1989; Anderson, 2009]. This leads to approaching climate change topics from indirect angles; if not about natural disasters, then climate change stories are linked with NGOs and international bodies and governmental measures

But we find the most illuminating approach for understanding the barriers faced by journalists in Pakistan attempting to provide adequate coverage of climate change issues is the structural approach. This approach focuses on the news-values, norms and news gathering sources that influence media coverage, and it is here we find the richest soil for our analysis. While the focus on sensational and 'hot and spicy' news stories is certainly very much part of the news-values of Pakistan's media, this is not unique to Pakistan. More specific for Pakistan is the lack of dedicated environmental journalists. But even more telling is the all-dominating view of politics as the core news-value item, and the structure this forms in terms of prestige and reward available to political journalists, while environmental issues are relegated to side projects for junior reporters. The other aspect the structural approach makes explicit is the news gathering norms, which, when it comes to environmental issues such as a climate change, are especially challenging. This is two fold; firstly, because of climate change's global nature, access to a range of information, most commonly accessed online, is essential. Yet, as we have shown, this is difficult both due to lack of resources, and due to lack of basic computer literacy. Secondly, the existing relationship between Pakistani climate scientists and journalists is structured such that there is little flow of information in either direction.

Conclusion and future research agenda
From the above discussion, we see that there is no doubt that political, economic, socio-cultural, and scientific and technological factors influence media coverage of climate change issues in Pakistan. And while some of these might have solutions, there are two primary challenges: access to information for journalists, and the low news-value of environmental stories (especially when compared to the overwhelming dominance of politics in this landscape). While it is beyond the scope of this paper to meaningfully suggest ways to address the low news-value of environmental issues, we can be more constructive about the 'access to information' challenge of Pakistani journalists. This latter challenge is two-fold. Firstly, it is technological in the sense that journalists need both the knowledge and resources to access information. Secondly, it is interactive in the sense that journalists need a way to interact with scientists, and vice versa. With regard to the technical challenge, it may be worthwhile noting and highlighting to NGOs and other providers of information that the fundamental needs are not so much for more information per se, but rather for more skills and resources to access already existing and already available information. As for the interactive challenge, there is a need for a framework and the development of new structures and networks that construct a scientific-journalistic relationship to improve the flow of information from scientists to the media, and from the media to the public, and from the public back to scientists. This paper provides the background and the first building blocks needed to build such a relationship. 
Appendix A.

Sources

\begin{tabular}{|c|c|c|c|c|c|c|c|}
\hline $\begin{array}{c}\text { Interv } \\
\text { iew } \\
\text { No }\end{array}$ & Type of Media & Gender & Age & $\begin{array}{l}\text { Years in } \\
\text { profession }\end{array}$ & POSITION / Role & $\begin{array}{l}\text { Language of } \\
\text { Media }\end{array}$ & Location \\
\hline 1 & TV & Male & 42 & 11 & News Producer & Urdu & $\begin{array}{l}\text { Islamabad/Rawalpi } \\
\text { ndi Pakistan }\end{array}$ \\
\hline 2 & News Agency & Male & 36 & 10 & Editor & English & $\begin{array}{l}\text { Islamabad/Rawalpi } \\
\text { ndi Pakistan }\end{array}$ \\
\hline 3 & $\begin{array}{c}\text { English } \\
\text { Newspaper }\end{array}$ & Male & 39 & 14 & Reporter Foreign News & English & $\begin{array}{c}\text { Islamabad/Rawalpi } \\
\text { ndi Pakistan }\end{array}$ \\
\hline 4 & TV & Male & 34 & 9 & TV Reporter & Urdu & $\begin{array}{l}\text { Islamabad/Rawalpi } \\
\text { ndi Pakistan }\end{array}$ \\
\hline 5 & $\begin{array}{l}\text { English } \\
\text { Newspaper }\end{array}$ & Male & 46 & 21 & Reporter & English & $\begin{array}{l}\text { Islamabad/Rawalpi } \\
\text { ndi Pakistan }\end{array}$ \\
\hline 6 & $\begin{array}{l}\text { English } \\
\text { Newspaper }\end{array}$ & Male & 28 & 6 & Reporter & English & $\begin{array}{l}\text { Islamabad/Rawalpi } \\
\text { ndi Pakistan }\end{array}$ \\
\hline 7 & $\begin{array}{l}\text { English } \\
\text { Newspaper }\end{array}$ & Male & 44 & 19 & Reporter & English & $\begin{array}{l}\text { Islamabad/Rawalpi } \\
\text { ndi Pakistan }\end{array}$ \\
\hline 8 & $\begin{array}{c}\text { Urdu } \\
\text { Newspaper }\end{array}$ & Female & 51 & 17 & Editor & Urdu & $\begin{array}{c}\text { Islamabad/Rawalpi } \\
\text { ndi Pakistan }\end{array}$ \\
\hline 9 & TV & Male & 32 & 7 & TV Reporter & Urdu & $\begin{array}{c}\text { Islamabad/Rawalpi } \\
\text { ndi Pakistan }\end{array}$ \\
\hline 10 & $\begin{array}{c}\text { Urdu } \\
\text { Newspaper }\end{array}$ & Female & 31 & 5 & Reporter & Urdu & $\begin{array}{l}\text { Islamabad/Rawalpi } \\
\text { ndi Pakistan }\end{array}$ \\
\hline 11 & $\begin{array}{c}\text { Urdu } \\
\text { Newspaper }\end{array}$ & Female & 42 & 11 & Editor & Urdu & $\begin{array}{c}\text { Islamabad/Rawalpi } \\
\text { ndi Pakistan }\end{array}$ \\
\hline 12 & TV & Male & 34 & 7 & News Reporter & Urdu & $\begin{array}{c}\text { Islamabad/Rawalpi } \\
\text { ndi Pakistan }\end{array}$ \\
\hline 13 & TV & Male & 53 & 18 & Bureau in Chief & Urdu & $\begin{array}{c}\text { Islamabad/Rawalpi } \\
\text { ndi Pakistan }\end{array}$ \\
\hline 14 & WEB TV & Male & 29 & 5 & Reporter & Urdu & $\begin{array}{c}\text { Islamabad/Rawalpi } \\
\text { ndi Pakistan }\end{array}$ \\
\hline 15 & Radio & Female & 37 & 9 & Reporter & Urdu & $\begin{array}{c}\text { Islamabad/Rawalpi } \\
\text { ndi Pakistan }\end{array}$ \\
\hline 16 & $\begin{array}{l}\text { English } \\
\text { Newspaper }\end{array}$ & Male & 28 & 3 & Reporter & English & $\begin{array}{c}\text { Islamabad/Rawalpi } \\
\text { ndi Pakistan }\end{array}$ \\
\hline 17 & WEB TV & Male & 29 & 6 & Reporter & Urdu & $\begin{array}{c}\text { Islamabad/Rawalpi } \\
\text { ndi Pakistan }\end{array}$ \\
\hline 18 & WEB TV & Female & 43 & 11 & Editor & Urdu & $\begin{array}{c}\text { Islamabad/Rawalpi } \\
\text { ndi Pakistan }\end{array}$ \\
\hline
\end{tabular}




\begin{tabular}{|c|c|c|c|c|c|c|c|}
\hline 19 & $\begin{array}{c}\text { Online } \\
\text { Newspaper }\end{array}$ & Female & 32 & 7 & Reporter & Urdu & $\begin{array}{c}\text { Islamabad/Rawalpi } \\
\text { ndi Pakistan }\end{array}$ \\
\hline 20 & $\begin{array}{c}\text { Online } \\
\text { Newspaper }\end{array}$ & Male & 44 & 13 & Reporter & Urdu & $\begin{array}{c}\text { Islamabad/Rawalpi } \\
\text { ndi Pakistan }\end{array}$ \\
\hline 21 & TV & Male & 57 & 17 & News Director & Urdu & $\begin{array}{c}\text { Islamabad/Rawalpi } \\
\text { ndi Pakistan }\end{array}$ \\
\hline 22 & TV & Male & 49 & 22 & News Director & Urdu & $\begin{array}{c}\text { Islamabad/Rawalpi } \\
\text { ndi Pakistan }\end{array}$ \\
\hline 23 & TV & Female & 39 & 13 & News Director & Urdu & $\begin{array}{c}\text { Islamabad/Rawalpi } \\
\text { ndi Pakistan }\end{array}$ \\
\hline 24 & TV & Male & 59 & 27 & Editor & Urdu & $\begin{array}{c}\text { Islamabad/Rawalpi } \\
\text { ndi Pakistan }\end{array}$ \\
\hline 25 & $\begin{array}{c}\text { English } \\
\text { Newspaper }\end{array}$ & Female & 51 & 19 & Editor & English & $\begin{array}{c}\text { Islamabad/Rawalpi } \\
\text { ndi Pakistan }\end{array}$ \\
\hline 26 & $\begin{array}{c}\text { Urdu } \\
\text { Newspaper }\end{array}$ & Male & 34 & 8 & Reporter & Urdu & $\begin{array}{c}\text { Islamabad/Rawalpi } \\
\text { ndi Pakistan }\end{array}$ \\
\hline 27 & Radio & Female & 29 & 6 & Reporter & Urdu & $\begin{array}{l}\text { Islamabad/Rawalpi } \\
\text { ndi Pakistan }\end{array}$ \\
\hline 28 & News Agency & Male & 38 & 10 & Reporter & English & $\begin{array}{c}\text { Islamabad/Rawalpi } \\
\text { ndi Pakistan }\end{array}$ \\
\hline 29 & News agency & Male & 42 & 15 & Editor & English & $\begin{array}{c}\text { Islamabad/Rawalpi } \\
\text { ndi Pakistan }\end{array}$ \\
\hline 30 & $\begin{array}{c}\text { Online } \\
\text { Newspaper }\end{array}$ & Female & 27 & 4 & Reporter & URDU & $\begin{array}{c}\text { Islamabad/Rawalpi } \\
\text { ndi Pakistan }\end{array}$ \\
\hline
\end{tabular}

Appendix B. Interview guide
Q.1 What does Climate Change mean to you?

Q.2. To what extend do you think national [Pakistani] media portrays the issue of climate change in its coverage of news?

Q.3 When reporting on climate change, what themes and content is being presented?

Q.4 What external factors (political, economic, social) do you believe influences climate change reporting?

Q.5 How do you think the media culture (internal factors) affects climate change reporting?

Q.6 To what extent do you feel scientists are an important source of information for journalists covering climate change? 
Q.7 How do you think Pakistani journalists use and interact with technology to produce climate change news stories?

Q.8 Would you like to add something or is there something you feel we did not cover?

\section{Appendix C. Nested themes}

\section{Reporting of climate change issues}

1. Event oriented news reporting
a. press conferences
b. press releases
c. weather forecasts
d. seminars
e. Conferences

2. Disasters oriented news
a. Floods
b. Drought
c. Femine

3. Foreign media reporting

a. $\mathrm{CNN}$ reporting

b. BBC reporting

\section{Business model as modus operandi}

1. Limited revenue generation

a. Private sector

i. Advertisements

ii. Subscription

b. Public sector(government)

i. Advertisements

ii. Subsidies

2. Limited access to foreign funding for climate change issues

a. Funding to Ngo

b. Funding to govt.

c. No funding to media houses

\section{Politicized media}

1. Media topics

a. Political parties,

b. Politicians

c. Ministers

d. Parliamentary issues

e. Political instability

2. Incentives for media

3. Political rewards for reporter

a. economic reward for reporter

4. Political affiliations with ruling and opposing parties 
News sociology

1. No regular beat of climate change news reporting

2. Junior staff / novice report climate change stories

3. News culture of Sensationalism

a. Breaking news syndrome/rat race

b. Hot and spicy new stories

\section{Technological backwardness}

1. Limited access to ICT

2. Ignorance of technology

3. Limited use of technology

4. Limit financial resources to buy media kit

\section{Scientific barriers}

1. Limited number of climatologist

2. Limited access to scientists

3. Secrecy of information

4. Self-interested goals of scientific institutions/scientists

Ali, Z. (2010). 'Domesticating Global Content Pakistan'. In: Global Climate local Journalisms: A transnational study of how media make sense of climate summits. Ed. by E. Eide, R. Kunelius and V. Kumpu. Bochum, Germany: ProjektVerlag.

Allan, S. (2004). News culture. Maidenhead, UK: Open University Press.

Allan, S., Adam, B. and Carter, C., eds. (2000). Environmental risks and the media. London, U.K.: Routledge.

Anderson, A. (2009). 'Media, Politics and Climate Change: Towards a New

Research Agenda'. Sociology Compass 3 (2), pp. 166-182.

https://doi.org/10.1111/j.1751-9020.2008.00188.x.

Antilla, L. (2005). 'Climate of scepticism: US newspaper coverage of the science of climate change'. Global Environmental Change 15 (4), pp. 338-352.

https://doi.org/10.1016/j.gloenvcha.2005.08.003.

Beck, U. (2009). World at risk. Cambridge, U.K.: Polity Press.

Beder, S. (2002). Global spin: The Corporate assault on environmentalism. Totnes, Devon, U.K.: Green Books.

Berger, P. L. and Luckmann, T. (1966). The social Construction of reality: a treaties in the sociology of knowledge. Garden City, N.Y., U.S.A.: Doubleday.

Biernacki, P. and Waldorf, D. (1981). 'Snowball Sampling: Problems and Techniques of Chain Referral Sampling'. Sociological Methods E Research 10 (2), pp. 141-163. https://doi.org/10.1177/004912418101000205.

Boykoff, M. T. (2011). Who speaks for the climate? Making sense of media reporting on climate change. Cambridge, U.K.: Cambridge University Press. 
Boykoff, M. T. and Boykoff, J. M. (2004). 'Balance as bias: global warming and the US prestige press'. Global Environmental Change 14 (2), pp. 125-136. https://doi.org/10.1016/j.gloenvcha.2003.10.001.

- (2007). 'Climate change and journalistic norms: A case-study of US mass-media coverage'. Geoforum 38 (6), pp. 1190-1204.

https://doi.org/10.1016/j.geof orum.2007.01.008.

Bygnes, S. (2008). 'Interviewing People-oriented Elites'. Eurospheres Online Working Paper no. 10.

Cottle, S. (2000). 'TV news, lay voices and the visualization of environmental risks'. In: Environmental risks and the media. Ed. by S. Allan, B. Adam and C. Carter. London, U.K.: Routledge, pp. 29-44.

- (2013). 'Environmental conflict in a global, media age: beyond dualisms'. In: Environmental Conflict and the Media. Global Crises and the Media. Ed. by L. Lester and B. Hutchins. Oxford, U.K.: Peter Lang, pp. 13-28.

Cox, J. R. (2013). Environmental Communication and the public sphere. 3rd ed. Thousand Oaks, CA, U.S.A.: SAGE Publications.

- (2015). 'Scale, Complexity, and Communicative Systems'. Environmental Communication 9 (3), pp. 370-378. https://doi.org/10.1080/17524032.2015.1044064.

Djerf-Pierre, M. (2012). 'When attention drives attention: Issue dynamics in environmental news reporting over five decades'. European Journal of Communication 27 (3), pp. 291-304. https://doi.org/10.1177/0267323112450820.

Gamson, W. A. and Modigliani, A. (1989). 'Media Discourse and Public Opinion on Nuclear Power: A Constructionist Approach'. American Journal of Sociology 95 (1), pp. 1-37. URL: http://www . jstor .org/stable/2780405.

Gelbspan, R. (2005). Boiling point: how politicians, big oil and coal, journalists, and activists are fueling the climate crisis and what we can do to avert disaster. New York, U.S.A.: Basic Books.

Gill, P., Stewart, K., Treasure, E. and Chadwick, B. (2008). 'Methods of data collection in qualitative research: interviews and focus groups'. British Dental Journal 204 (6), pp. 291-295. https://doi .org/10.1038/bdj .2008.192.

Hansen, A. (2010). Environment, media and communication. London and New York: Routledge.

- (2015). 'Promising Directions for Environmental Communication Research'. Environmental Communication 9 (3), pp. 384-391. https://doi.org/10.1080/17524032.2015.1044047.

Hilgartner, S. and Bosk, C. L. (1988). 'The Rise and Fall of Social Problems: A Public Arenas Model'. American Journal of Sociology 94 (1), pp. 53-78. https://doi.org/10.1086/228951.

Hutchinson, S. and Wilson, H. S. (1992). 'Validity Threats in Scheduled Semistructured Research Interviews'. Nursing Research 41 (2), pp. 117-119. https://doi.org/10.1097/00006199-199203000-00012.

Kim, S. Y. (2011). 'Public Perceptions of Climate Change and Support for Climate Policies in Asia: Evidence from Recent Polls'. The Journal of Asian Studies 70 (02), pp. 319-331. https://doi.org/10.1017/s0021911811000064.

Kvale, S. (2007). Doing Interviews. London, U.S.A.: SAGE Publications, Ltd. https://doi.org/10.4135/9781849208963. 
Miller, M. M. and Riechert, B. P. (2000). 'Internet group strategies and Journalistic norms: News media framing of environmental issues'. In: Environmental risks and the media. Ed. by S. Allan, B. Adam and C. Carter. London, U.K.: Routledge, pp. 45-54.

Monbiot, G. (2006). Heat: how to stop the planet burning. London and New York: Allen Lane.

Rhaman, M. (2012). 'Applying advocacy in climate change. The case of Bangladesh'. In: Media Meets Climate: The global challenges for journalism. Ed. by E. Eide and R. Kunelius. Nordicom, pp. 145-162.

Ricchiardi, S. (2012). Challenges for Independent News Media in Pakistan. Center for International Media Assistance. URL: https://reliefweb.int/report/paki stan/challenges-independent-news-media-pakistan.

Schäfer, M. S. and Schlichting, I. (2014). 'Media Representations of Climate Change: A Meta-Analysis of the Research Field'. Environmental Communication 8 (2), pp. 142-160. https://doi.org/10.1080/17524032.2014.914050.

Smith, J. A., Larkin, M. and Flowers, P. (2009). Interpretative Phenomenological Analysis: Theory, Method and Research. Los Angeles and London: SAGE.

Smith, J. A. and Osborn, M. (2007). 'Interpretative phenomenological Analysis'. In: Qualitative psychology: A practical guide to research methods. Ed. by J. A. Smith. London, U.K.: Sage.

Sullivan, J. L. (2004). 'On the rewards and perils of "studying up". Practical strategies for the qualitative research on media organizations'. Paper presented at the 24th IAMCR Conference, Porto Alegre, Brazil. URL: http://citeseerx . i st.psu .edu/viewdoc/download?doi=10.1.1.454.2231\&rep=rep1\&type=pdf (visited on 7th March 2018).

TNN (30th June 2014). 'About'. The Nature News. URL: http: //thenaturenews . com/about/ (visited on 8th February 2017).

Undheim, T. A. (2003). 'Getting connected: how sociologists can access the high tech elite'. The Qualitative Report 8 (1), pp. 104-128.

URL: http://nsuworks . nova. edu/tqr/vol8/iss1/8/.

World Bank (2015a). Data: Pakistan.

URL: http://data. worldbank. org/country/pakistan.

- (2015b). Rural population (\% of total population).

URL: http://data. worldbank .org/indicator/SP. RUR. TOTL . ZS.

- (2018). CO2 emissions (kt): Pakistan. URL: https ://data. worldbank.org/indicat or/EN. ATM. CO2E. KT?locations=PK.

Yusuf, S. (21st October 2008). 'Pakistan launches task force on climate change'. Scidev.net. URL: http://www.scidev.net/global/climate-change/news/pakis tan-launches-task-force-on-climate-change.html.

Zaheer, K. and Colom, A. (2013). Climate Asia Report Pakistan: How the people of Pakistan live with climate change and what communication can do. BBC Media Action. URL: http://downloads.bbc.co.uk/rmhttp/mediaaction/pdf/climate asia/reports/country/ClimateAsia_PakistanReport.pdf (visited on 10th February 2017). 
Asim Sharif is doctoral student in the Centre for Science Communication at the University of Otago in New Zealand. His PhD project is Conceptualizing Climate Change Media Science Communication: A Scientific-Journalistic Relational Model. E-mail: asimsharif89@yahoo.com.

Fabien Medvecky is a lecturer in science communication at the University of Otago's Centre for Science Communication and is the president of the Science Communicators' Association of New Zealand. With a background in philosophy of science, and environmental economics, he previously lectured at the University of Queensland's program in science communication.

E-mail: fabien.medvecky@otago.ac.nz.

How to cite

(C) The Author(s). This article is licensed under the terms of the Creative Commons Attribution - NonCommercial — NoDerivativeWorks 4.0 License.

ISSN 1824-2049. Published by SISSA Medialab. jcom.sissa.it 